\title{
Interdisciplinary Professional Development for Teaching Science and Reading
}

\author{
JACOB WHITE', DENISE SHOCKLEY ${ }^{2}$, MARGARET HUTZEL' ${ }^{3}$ NATALIE WILSON ${ }^{4}$ \\ ${ }^{1}$ Associate Professor of Chemistry, University of Rio Grande ${ }^{2}$ Superintendent, Gallia-Vinton Educational Service Center ${ }^{3}$ Senior Research \\ Associate, Ohio University ${ }^{4}$ Research Associate, Ohio University
}

\begin{abstract}
Because instructional demands in literacy in the lower grades often limit instructional opportunities in other areas, including science, interdisciplinary approaches to training science educators are of current interest. This article describes the structure and impact of professional development activities for elementary and middle school teachers within a rural Ohio public school district (Gallia County Local) that aimed to address needs in both science and literacy. All teachers $(n=39)$ of grades three through eight who taught science and/or reading, including special education teachers, received targeted training on Earth \& Space Science content and pedagogy and on strategies for teaching non-fiction reading within the science curriculum. Additional professional development was provided through one-on-one academic coaching sessions with teachers in their respective classrooms. Pre- and post-training teacher surveys were compared using a Wilcoxon signedranks test to determine statistical significance $(a=0.05)$ of any observed differences. The results indicate significant changes in instructional practices of participating teachers in several key areas, including increased usage of nonfiction reading $(p=0.04)$ and differentiated instructional practices within the science curriculum $(p=0.05)$. Comparison of student achievement scores on selected components of state-level assessments in reading and science also suggest a positive impact of the professional development in some areas. An increase in student proficiency in informational text and Earth \& Space Science was observed after teachers received the training compared to the year prior to the training.
\end{abstract}

OHIO J SCI 114(2): 2-10

\section{INTRODUCTION}

The importance of increasingscientificliteracy in the general population is well documented (AAAS 1990a, AAAS 1990b, NRC 1996, NRC 2007, NSF 2010). As society continues to be driven by science and technology, functional scientific literacy has been deemed necessary for any individual to be a responsible and conscientious citizen (Laugksch 2000, Shamos 1995, McPhearson and others 2008). However, increasing burdens, such as time constraints and high stakes testing, have forced some public school districts in recent years to decrease the amount of time and/or emphasis devoted to the science curriculum, especially in lower grades. This has spurred much discussion regarding possibilities for cross-disciplinary instructional strategies, such as teaching reading and science in a concurrent manner via increased usage of non-fiction reading within the science curriculum. Such strategies provide the benefit of increasing the amount of time potentially spent on science instruction. However, such strategies also increase the demands placed on teachers. Research suggests that quality teaching specific to reading

${ }^{1}$ Address correspondence to Jacob White, Associate Professor of Chemistry, University of Rio Grande, 218 N. College Avenue, Rio Grande, OH 45674, jwhite@rio.edu readiness requires educators in the early and middle childhood years to be immersed in knowledge about language and literacy development (Dickinson 2006). Effective science instruction is also likely correlated with the degree of content training of teachers. Considering that many multi-level analyses (Howes 1997, National Institute of Child Health and Human Development 2002, Phillipsen 1997) have reported teacher quality as a greater predictor of student skills than class size, school content and other related variables, the need for professional training opportunities in districts considering cross-disciplinary instructional strategies that combine reading and science is evident.

Research regarding design and effectiveness of professional training in both science and reading is limited. Although policy makers in recent years have targeted teachers of young children for greater professional development efforts through such examples as Early Reading First (No Child Left Behind Act 2002) and Good Start, Grow Smart (U.S. Department of Health and Social Services 2002), researchers still have limited knowledge about the effectiveness of such professional training, or the impacts of the trainings on the instructional practices of teachers (Neuman 2009). Furthermore, the spirit of such policy changes did not include the 
cross-disciplinary integration of science with literacy training. Also lacking in these policy changes has been the emphasis on family involvement. Some research has demonstrated the importance of family involvement in the creation of reciprocal relationships that support the development of literacy skills (Dickinson 2006). It is therefore speculated that family involvement may play a supportive role in students' learning and development in all areas, includingscience. In the recent report Taking Science to School (Duschl 2007), the National Research Council (NRC) summarized that empirical research is still needed on the overall practices of building expertise in science teaching. This NRC report (Duschl 2007) also underscores the necessity for both teachers and parents to assist in children's learning of science, consistent with research (Dickinson 2006) emphasizing the necessity for parents to assist in children's development of literacy skills.

In an effort to contribute to the knowledge base for effective professional training of in-service teachers, this article describes the structure of interdisciplinary training in science and reading and its impact on teacher practices and student achievement.

\section{STRUCTURE OF PROFESSIONAL DEVELOP- MENT PROJECT IN SCIENCE AND READING}

The Gallia County Local School District from the Southeast Ohio region identified teacher needs in science and reading and formed a partnership with the science department at a nearby university as well as an educational service center (ESC) to provide inservice training to address these needs. Activities were primarily funded through a state-level grant, issued to the private university. The partnering school district was rural, encompassing nearly 400 square miles, and included five elementary schools, one middle school and two high schools. The average daily enrollment within the district at the time of the training was 2,432 students, with $96.1 \%$ of students being identified as white and $54.2 \%$ of students being identified as economically disadvantaged (2009-2010 District Report Card). All teachers of grades three through eight who taught science and/or reading in the target district participated in this professional development project, including those special education teachers who worked in concert with science and/or reading teachers in inclusion settings. A total of 39 teachers participated in the project, although not all 39 teachers participated in all activities (there were some absences due to illness, conflicts, etc.).
The Educational Service Center was contracted to recruit, hire and train academic coaches from the area who would provide one-on-one coaching sessions with the participating teachers in their classrooms. The academic coaches were selected based on demonstrated expertise in either science or literacy. Most of the coaches hired for this project were well respected, certified Master Teachers who had retired from surrounding districts in recent years. The private university served as the fiscal agent and supported the Principal Investigator for the project, a full-time science faculty member with experience in STEM-focused professional development for in-service teachers. External facilitators were hired to deliverworkshops to participating teachers throughout the academic year. An external evaluation team was contracted to evaluate the project relative to the stated goals of the partnership.

By providing targeted professional development activities in content and pedagogy to all teachers of science and reading in grades three through eight in the partnering school district and by providing activities that would expose parents to their students' science curriculum, the project's aim was to increase student achievement in science and reading. The following five specific goals of the project were articulated for participating teachers and their students:

1. Increase usage of nonfiction reading within the science curriculum

2. Increase inclusion of differentiated instructional practices within the science curriculum

3. Increase science content knowledge of students

4. Increase the students' motivation for literacy

5. Increase parental participation in after school science activities

To accomplish these goals, participating teachers engaged in a four day workshop focusing on content and related pedagogy surrounding the Earth \& Space Science strand of the state science standards, as well as a two day workshop focusing on the teaching of non-fiction reading within the science curriculum. In addition, participants had the opportunity for follow-up one-on-one academic coaching sessions throughout the academic year in their own classrooms. Nearly all of these professional development activities occurred during the normal school day (i.e., "on-theclock"), ensuring the partnering district was able to commit $100 \%$ of its science and reading teachers to the project, including teachers with the greatest needs. Details regarding the focus of each of these activities are presented in the following section. 


\section{FOCUS OF PROFESSIONAL DEVELOPMENT ACTIVITIES}

A four day workshop focusing on content and related pedagogy surrounding the Earth \& Space Science strand of the state science standards was delivered to participating teachers. This workshop module was based on work supported by the Ohio Department of Education (ODE grant number OSCI 7-10 3D2G200-667-OSCI-04DR-02), and included five unitstopography, earthquakes, volcanoes, paleomagnetism, and plate tectonics. Although the workshop included materials that teachers could use in their classrooms, the workshop was designed with the primary objective of improving teacher content and pedagogical knowledge. Throughout the workshop units, the inquiry method of teaching was followed as much as possible, and activities conveyed the following key ideas: 1.) scientific data are real; 2.) scientific data come from many individuals all over the world who have taken measurementsin a manner similar to the methods used in the workshop activities; and 3.) science is both a body of data that has been accumulated and a process that is followed to accumulate data. All activities used throughout the workshop were designed to lead to conclusions about plate tectonics, stressing that the discovery of patterns in scientific data of topography, spatial distributions of earthquakes and volcanoes, and paleomagnetism have led to the theory of plate tectonics. An external facilitator trained and approved by ODE to deliver this workshop module was hired to provide the training to participants on staggered days during the academic year. Participants received a total of 32 contact hours of professional development relative to this training.

A two day workshop focusing on content and related pedagogy surrounding the teaching of non-fiction reading within the science curriculum was also offered to participating teachers. This workshop was designed and delivered by an external facilitator from the Midcontinent Regional Educational Laboratory (www. mcrel.org), and overviewed key premises to teaching content reading skills. These key premises included schema theory, prior knowledge, metacognition, the reading and writing relationship, collaborative interactions, as well as interactive elements of reading (reader, climate, and text features). Participants were trained on systematic vocabulary instruction, such as using nonlinguistic representations, concept definition mapping, semantic mapping, and verbal and visual word association. Participants were also trained on text style/ structure, with special emphasis on informational text as it is the prevalent text style implemented in science curricula. Participants received a total of 16 contact hours of professional development relative to this training.

In addition to workshop training, academic coaching sessions occurred on-site with participating teachers throughout the school year to provide individualized professional development opportunities as well as follow-up sessions relevant to the workshop training. Although originally designed as a mathematics coaching model, these coaching sessions were loosely guided by David Foster's pedagogical content coaching model (Foster and Poppers 2009), with the ultimate goal of the one-on-one sessions being the improved instruction of each participating teacher. The fundamentals of the coaching model were to create a trusting relationship between the coach and teacher, to utilize effective listening skills and strategic questioning to promote reflection by the teacher, and to employ data collection and thoughtful feedback related to teacher and student behaviors. The sessions often included team teaching activities, lesson modeling by the coach, and/ or constructive observation by the coach of a lesson delivered by the participating teacher. Various coaches with differingareas of expertise (science or literacy) were available to the teachers throughout the year. Sessions were scheduled between a coach and a participating teacher on an individual basis in an effort to prevent the sessions from interfering with other facets of the teachers' schedules. The number of coaching sessions and nature of the coaching sessions varied greatly between participating teachers and coaches.

In addition to these professional development activities, teachers were also tasked with helping to design and deliver science-focused "Family Night" events at each of the four schools within the target district. These events aimed at engaging families in their children's science education. One event was hosted by each of the partnering schools in the spring of the project year. At each event, there were various activities available throughout the school. The main activities included a 20-minute bug show and inflatable star lab, both provided by a local center for the arts and sciences (the Clay Center, Charleston, WV), and a talk about an author's science-relevant experiences in a rainforest, which was structured to be appropriate for both parents and children. Students and parents rotated through rooms housing short (15 minute) teacherguided activities including "Color Changing Milk," "Invisible Balloon and Screaming Balloon," "Hoopster 
Air Planes," and "Celts, Mystery Sticks and Floating Rice," which were adopted from various elementary science education resources.

\section{IMPACT OF PROFESSIONAL DEVELOPMENT ON TEACHER PRACTICES AND STUDENT ACHIEVEMENT}

To assess the efficacy of the professional development activities, impacts were assessed using quantitative and/ or qualitative measures with data collected from key project personnel, participating teachers, parents, and students who attended the target district. Specific data sources included student achievement scores on statelevel exams in science and reading, student vocabulary and reading attitude assessments, instructional practices surveys, and Family Night observations and participant satisfaction surveys.

\section{Impact on Teachers}

The project's impact on changes in the instructional practices of participating teachers was assessed relative to increased usage of nonfiction reading and inclusion of differentiated instructional practices within science curriculum. Participants completed a 26-item instructional practices survey prior to the training and again at the end of the school year, which required them to rate items regarding specific instructional practices using a frequency scale from zero to four where zero indicated none, 1 little, 2 some, 3 moderate, and 4 considerable. Of the 36 participating teachers, 25 teachers had matching pre- and post-assessment measurements. The results were analyzed using a Wilcoxon signed-ranks test to determine statistical significance $(\alpha=0.05)$ of any observed differences between pre- and postmeasurements. Statistically significant positive changes indicated that after the completion of the professional development activities more science class time was being allowed for addressing students' strengths and needs and for giving students more opportunities to display their individual strengths (i.e., differentiated instructional practices), and also for students to read about science in books, magazines and articles that were not textbooks (i.e., increased usage of non-fiction reading within the science curriculum). A statistically significant positive change also indicated that after the completion of the professional development activities more science class time was being allowed for students to work on real world problems that were relevant to the student. Table 1 summarizes the positive impact on teachers' instructional practices.

\section{Impact on Students}

Student achievement gains were assessed bycollecting de-identified student-level data on state achievement tests. State student achievement in readingwas assessed at allgradelevels in thisstudy. However, sciencewas assessed only at the fifth and eighth grade levels. In addition, because all teachers of science and/or reading in the target grades participated in the professional development activities, the district's student achievement data in reading and science were analyzed in aggregate. The impact on students of participating teachers was assessed to determine if the professional development activities resulted in an increase in students' motivation for literacy, as well as an increase science content knowledge of students. A modified Elementary Reading Attitude Survey (McKenna and Kear 1990) was employed to assess change in student motivation for literacy. A positive change from pre- to post-measures would indicate that students reported more positive feelings about the questions asked in the post-test, and a negative change indicates that students feel less positively about what is asked. Students completed the instrument in the fall and again in the spring. Five hundred and seventy-four students' pre-tests were matched to their post-tests. For each question, students were given a choice of "I really don't like it," "I don't like it," "It's okay," "I like it," or "I really like it." The responses were scored on a scale of one to five, and the average scores for the pre-test and the post-test were then compared using a Paired Samples T-Test for statistical significance $(\alpha=0.05)$.

The student surveys show mixed results regarding the students' motivation towards literacy, yet generally appeared to become less positive over the course of the academic year. A statistically significant change was observed in how the students felt about reading a book in school during free time, reading for fun at home, getting a book for a present, spending free time reading, reading different kinds of books, reading in school, reading school books, using a dictionary, and reading in science class. All of these changes show that the students felt less positively about the stated questions. However, a statistically significant positive change was observed in how the students felt about reading a book on a rainy Saturday, about going to a bookstore, when they read out loud in class, about taking a reading test, about reading science books, and about learning from science books. Aggregate analysis of the 574 matching surveys showed that 303 students' scores decreased (became less positive) while 238 increased (became more positive) and 33 remained unchanged. 
TABLE 1

Pre- and post-measures of positive changes to instructional practices of participating teachers. Highlighted $p$ values indicate areas with statistically significant positive changes.

\begin{tabular}{|c|c|c|c|}
\hline Questions & $\begin{array}{c}\text { Mean } \\
\text { Pre }\end{array}$ & $\begin{array}{c}\text { Mean } \\
\text { Post }\end{array}$ & $\begin{array}{c}\text { p Value } \\
\text { (Wilcoxon } \\
\text { Signed-Ranks) }\end{array}$ \\
\hline
\end{tabular}

How much of the target science class time do students use to engage in the following instructional tasks:

$\begin{array}{llll}\text { Have opportunities to display individual strengths } & 2.72 & 3.04 & .06 \\ \text { Work on activities that reinforce that each student is a unique } & 2.60 & 2.72 & .52 \\ \quad \text { individual with different learning needs } & & & .45 \\ \text { Work on different tasks according to their strengths and needs } & 2.44 & 2.88 & .05 \\ \text { Learn from lesson plans that center on big ideas or major concepts } & 3.08 & 3.32 & .35 \\ \text { Do anchoring activities between assignments } & 2.38 & 2.63 & .19 \\ \text { Write about science in a report or paper on science topics } & 2.00 & 2.21 & .42 \\ \text { Read about science in books, magazines, or articles (not textbooks) } & 2.52 & 3.00 & .04 \\ \text { Maintain and reflect on a science portfolio of their own science work } & 1.56 & 1.96 & .10\end{array}$

When students in the target class work in assessment activities as a part of science instruction, how much time do they:

Work on activities that diagnose differences in learning style

Engage in activities that utilize a variety of performance indicators

Work with curricula that are designed to assess knowledge

Participate in on-going activities that drive curricular planning
2.08

2.91

3.00

2.48

2.12

3.09

3.08

2.76
.85

.38

.49

.11

When students in the target class work on science tasks how much of that time do they:

\begin{tabular}{|c|c|c|}
\hline $\begin{array}{l}\text { Work with reading buddies getting experience reading with peers to } \\
\text { develop fluency and comprehension }\end{array}$ & 2.68 & 2.72 \\
\hline $\begin{array}{l}\text { Engage in tiered activities as ways of reaching the same goals according } \\
\text { to individual student needs }\end{array}$ & 2.16 & 2.40 \\
\hline $\begin{array}{l}\text { Do independent study to develop skills for independent } \\
\text { learning and research }\end{array}$ & 2.04 & 2.20 \\
\hline $\begin{array}{l}\text { Work on real world problems that are relevant to the student } \\
\text { and the activity }\end{array}$ & 2.36 & 2.76 \\
\hline
\end{tabular}

In addition to these attitude surveys, student achievement data on state-level reading assessments were also analyzed. One method for analyzing the project's impact on students with regards to literacy was to compare students' scores in reading from the year prior to the project with students' scores from the end of the project year. For example, scores from third grade students the year prior to the project were compared with their individual scores for the assessment administered at the end of the project year, during which they were in the fourth grade. Students whose scores were not available for either year were excluded, as were students who were identified as having an Individual Education Plan (IEP) in reading for either year as these students may have been tested using an alternative assessment instrument. The first analysis of student reading assessment data examined the number of students who were proficient or above in the subcategory of 
Reading Informational Text, since this subcategory was perceived as being the most closely related to goals of the professional development activities. When summed, it was observed that across grades 3 through 8 , a total of 81 more students were proficient or above in informational text at the end of the project year than in the year prior to the project year. Table 2 shows the target district's proficiencylevels in the Informational Text subcategory as compared to the state and "like districts" (determined by the Ohio Department of Education for each district using various metrics). Though not matched groups of the exact same students, the cohorts of students within the district moving from one grade to the next across years can be compared for change. Four out of the five groups with two years of data (third through seventh graders in the year prior to intervention, who moved to fourth through eighth in the intervention year) had an increase in the percentage of students above proficient in readinginformational text. It should be noted, however, that like districts also had similar improvements as did the state, and the eighth grade gain was greater in the like districts and the state. Student reading scores were also compared to determine scoring differences at the individual student level from year 1 to year 2 . Students who did not have scores for both years and students with IEPs were not included in the analysis. Overall, slightly more students' total reading scores increased (n $=346)$ than decreased $(n=330)$ from 2009 to 2010 .
Table 3 compares the state, like districts, and the target district on student achievement in the Earth and Space Science content standard strand of the state achievement test from the year prior to the project and again for the intervention year, as this subcategory was perceived as being the most closely related to goals of the professional development activities. These data represent the percentage of students scoring above proficient on this strand of the assessment. Eighth grade students from the target district showed a slight gain from before to after their teachers received the intervention, although it should be noted that these are different students. In addition, any increase in proficiency cannot be exclusively attributed to the intervention as this comparison lacked a control group design. However, by comparing changes within the target district with changes in both similar districts as well as the entire state, some degree of impact from the project can be determined. At the fifth grade level, both the state average and average for similar districts decreased over this time period, yet the target district performance level stayed constant. Although the increase in performance within the target district at the eighth grade level was not as substantial as that observed for both the state average and average for similar districts over this time period, the target district did increase its performance to a level considerably higher than observed elsewhere in the state.

TABLE 2

State and district comparison of student proficiency in Reading Informational Text (\% Proficient). Arrows track student cohort progression from the year prior to teachers receiving training to the end of the intervention year.

\begin{tabular}{|c|c|c|c|c|c|c|}
\hline & \multicolumn{3}{|c|}{ Year Prior to Intervention } & \multicolumn{3}{|c|}{ At the End of Intervention Year } \\
\hline & $\begin{array}{c}\text { Target } \\
\text { District }\end{array}$ & $\begin{array}{c}\text { Like } \\
\text { Districts }\end{array}$ & State & $\begin{array}{c}\text { Target } \\
\text { District }\end{array}$ & $\begin{array}{c}\text { Like } \\
\text { Districts }\end{array}$ & State \\
\hline 3rd Grade & $39 \%$ & $35 \%$ & $37 \%$ & $34 \%$ & $39 \%$ & $38 \%$ \\
\hline 4th Grade & $58 \%$ & $54 \%$ & $58 \%$ & $\rightarrow 42 \%$ & $54 \%$ & $44 \%$ \\
\hline 5th Grade & $33 \%$ & $25 \%$ & $33 \%$ & $\rightarrow 32 \%$ & $33 \%$ & $38 \%$ \\
\hline 6th Grade & $39 \%$ & $47 \%$ & $50 \%$ & $\rightarrow 49 \%$ & $57 \%$ & $56 \%$ \\
\hline 7th Grade & $41 \%$ & $38 \%$ & $42 \%$ & $\rightarrow 43 \%$ & $43 \%$ & $46 \%$ \\
\hline 8th Grade & $47 \%$ & $38 \%$ & $39 \%$ & $\rightarrow 40 \%$ & $45 \%$ & $43 \%$ \\
\hline
\end{tabular}


TABLE 3

\section{Percentage of students above proficient in Earth and Space Science portion} of the state achievement tests.

\begin{tabular}{lcccccc}
\hline \hline & \multicolumn{2}{c}{ Year Prior to Intervention } & \multicolumn{2}{c}{ At the End of Intervention Year } \\
& $\begin{array}{l}\text { Target } \\
\text { District }\end{array}$ & Like & State & Target & Like & State \\
& $14 \%$ & $15 \%$ & $19 \%$ & District & Districts & $16 \%$ \\
\hline 5th Grade & $32 \%$ & $16 \%$ & $19 \%$ & $36 \%$ & $23 \%$ & $27 \%$ \\
\hline 8 th Grade & & & & $12 \%$ & $16 \%$ \\
\hline
\end{tabular}

\section{Impact on Parental Engagement}

Parental engagement was assessed through an observation conducted at one of the school-based Family Nights, staff interviews and parent survey responses. In total, over 1,000 parents/community members attended the Family Night events. The response from parents, children and staff was overwhelmingly positive. A satisfaction survey was distributed at each of the events, and 205 completed surveys were returned. Only 24 respondents indicated they had attended a prior science night event. On a scale of one to ten (with one being the lowest and ten being the highest), survey respondents rated the event they attended as 9.3 both in overall quality and in regards to how well they perceived the event as a learning experience. When the data were separated by school, there was little difference among them or in comparison to the overall means. That is, the average response by school on the same survey questions was between nine and ten. When asked whether those who attended an event learned anything related to science at the event, over 90 percent of the responding parents indicated "yes." The same is true when each school's data were considered individually. The survey also queried parents about how often they encourage their children to read about science and how often they talk with their children about science. Nearly $70 \%$ of the respondents indicated they often or very often encourage their children to read science-related materials. This same response rate was also observed when asked how often parents talk to their children about science-related topics. Parents were also asked to provide comments about the science night they attended. Below is a list of representative comments that include one comment from an attendee from each school building:

* "Have these more often. It generates interest in science. I thought the exhibits were perfect for the age group attending."
* 'It's awonderfulhands-on experience forchild \& adult; It lets them apply what they have learned \& open their mind to new possibilities."

* "We need more events throughout the year like this."

* "I liked it very much; great learning and family time." Collectively, these results suggest the activities were successful at promoting parental engagement in their children's science education, at least temporarily.

\section{CONCLUSIONS}

Increasing burdens, including time constraints and high stakes testing, have forced some public school districts in recent years to decrease the amount of time and/or emphasis devoted to the science curriculum, especially in lower grades. When education funding formulas penalize districts for underperformance in math and reading, yet do not penalize or penalize less for underperformance in science, the resources devoted to science instruction are quickly reinvested in other areas. Thus, interest in interdisciplinary approaches to teaching other disciplines within the science curriculum, including math and reading, is growing. Such strategies provide the benefit of increasing the amount of time potentially spent on science instruction while remaining cognizant of other needs. However, such strategies also increase the professional demands placed on teachers. To be exemplary at teaching science, educators must have strong content and pedagogical knowledge across the various strands of science. This, in itself, is a difficult task, especially when considering the rate of scientific discoveries and new advances in theoretical models. To then additionally task teachers with becoming exemplary in their abilities to teach literacy skills is even more difficult, warranting considerable in-service training opportunities. This report provides a description of the professional development activities and their impact on teacher practices and student achievement, and it may 
provide educators with guidance in the planning of related professional development activities.

Analysis of the teacher instructional practices pre- and post-test data indicates that the professional development activities offered through this project were effective in increasing the usage of nonfiction readingand differentiated instructional practices within the science curriculum. The reported changes were particularly relevant given that the training activities specifically targeted science and literacy needs. Analysis of student achievement data may also indicate that the training was effective in increasing student content knowledge in science and reading. However, the assessment instruments and methodology used with respect to student-level impact were selected out of economic necessity. This project was not designed nor intended to provide validated results concerning its impact, and the project budget did not permit such evaluation methods and/or instruments. Although the use of state achievement tests to compare differences in proficiency is cost-effective, the transient nature of such instruments and the absence of a control group evaluation design make such a determination difficult. In addition, studies comparing the results from validated instruments that assess student content knowledge with state achievement tests in science have revealed significant discrepancies in the levels of student achievement as well as in student achievement gains (Koretz and Baron 1998, Lee 2007, Linn and others 2002). Regardless, the cost-effectiveness of such state-level student data warranted the usage of these instruments. Further, this metric may be of primary concern to district administrators when planning related in-service training (i.e., will the training increase state test scores?). Interestingly, the student survey results appear to indicate that the project's activities were not effective in increasing students' motivation for literacy. Survey results showed that positive student attitudes towards reading declined from fall to spring during the intervention year. Although related changes in student attitudehave been reported previously (Hill and others 1995, Shrigley 1990, Simpson and Oliver 1985, Simpson and Oliver 1990, Talton and Simpson 1985), student fatigue at the end of the school year may have also contributed to attitudinal changes. With respect to impact on the parent-level, the assessment results suggest that the Family Night activities were very effective in promoting parental engagement in their children's science curriculum, at least through their short-term participation in the after school science activities. It is not clear if/how this engagement translated into student achievement or motivation. However, parental involvement and support should not be underestimated in influencing student achievement. Even short term increases in parental engagement have the potential for meaningful impact on student achievement.

When considering engagement in a district-level professional development project, educators need assurance that there will be a positive impact at both the teacher and student levels with respect to the time and effort that will be required. The activities described in this report provided the opportunity for the teachers involved to receive a substantial amount of training in both science and reading. The pre- and post-measurement for the teachers suggest significant improvements in instructional practices in some key areas. For students, it is difficult to conclusively assess the impact of the project given the short time frame of the evaluation and the methodology employed. However, student achievement scores in reading (Informational Text) and science (Earth \& Space Science) improved, and the assessment data also suggest the time and effort was effective in engaging parents in actively taking part in educational science activities with their children. In summary, this report describes activities that could be easily replicated by other school districts, and provides evidence that interdisciplinary professional development which aims to increase science and reading content knowledge and classroom practice can effect positive teacher change and improved student achievement.

\section{ACKNOWLEDGEMENTS}

This study was funded by an Improving Teacher Quality grant award made by the Ohio Board of Regents, grant 08-35.

\section{LITERATURE CITED}

2009-2010 Gallia County Local School District Report Card. Ohio Department of Education.

[AAAS] American Association for the Advancement of Science. 1990. Science for All Americans: Project 2061. New York: Oxford University Press.

[AAAS] American Association for the Advancement of Science, Project on Liberal Education and the Science. 1990. The Liberal Art of Science: Agenda for Action. Washington, DC.

Dickinson D, Brady J. 2006. Toward effective support for language and literacy through professional development. In Zaslow M, Martinez-Beck I, editors. Critical issues in early childhood professional development. Baltimore, MD: Brookes.p 141-170.

Foster D, Poppers A. 2009. The Silicon Valley Mathematics Initiative: A twelve-year research and development project. Noyce Foundation webpagehttp://www.svmimac.org/images/ Using_Formative_Assessment_to_Drive_Learning_Reduced. pdf. Accessed 2013 Aug 6. 
Hill G, Atwater M, Wiggins J. 1995. Attitudes toward science of urban seventh-grade life science students overtime, and the relationship to future plans, family, teacher, curriculum, and school. Urban Education 30(1):71-92.

Howes C. 1997. Children's experiences in center-based child care as a function of teacher background and adult-child ratio. Merrill-Palmer Quarterly, 43:404-425.

Koretz D, Barron S. 1998. The validity of gains on the Kentucky Instructional Results Information System (KIRIS) (MR-1014EDU), Santa Monica, CA: Rand.

Laugksch RC. 2000. Scientific literacy: A conceptual overview. Science Education 84(1):71-94.

Lee J. 2007. The testing gap: Scientific trials of test-driven school accountability systems for excellence and equity. Charlotte, NC: Information Age Publishing.

Linn RL, Baker EL, Betebenner DW.2002. Accountability systems: Implications of requirements of the No Child Left Behind Act of 2001. Educational Researcher 31:3-16.

McKenna MC, Kear DJ. 1990. Measuring attitude toward reading: A new tool for teachers. The Reading Teacher 43(8):626-639.

McPhearson PT, Gill SPD, Pollack R, Sable JE. 2008. Increasing scientific literacy in undergraduate education: A case study from "frontiers of science" at Columbia University. In Darbellay F, Cockell M, Billotte J, Waldvogel F, editors. A vision of transdisciplinarity: Laying foundations for a world knowledge dialogue. Lausanne, Switzerland: EPFL Press. P 148-161.

[NICHD] National Institute of Child Health and Human Development Early Child Care Research Network. 2002. Child care structure-process-outcome: Direct and indirect effects of child care quality on young children's development. Psychological Science 13(3):199-206.

[NRC] National Research Council, Center for Science, Mathematics, and EngineeringEducation. 1996. From analysis to action: Undergraduate education in science, mathematics, engineering, and technology. Washington, DC: National Academies Press.
[NRC] National Research Council, Committee on Science Learning, Kindergarten through Eighth Grade. 2007. Taking science to school: Learning and teaching science in grades k-8. Washington, DC: National Academies Press.

[NSB] National Science Board. 2010. Science and Engineering Indicators 2010. Arlington, VA:National Science Foundation (NSB 10-01).

Neuman SB, Cunningham L. 2009. The impact of professional development and coaching on early language and literacy instructional practices. American Educational Research Journal 46(2):532-566.

No Child Left Behind Act. 20 USC. $\$ 6301$ et seq. (2002).

Phillipsen L, Buirchinal M, Howes C, CryerD. 1997. The prediction of process quality from structural features of child care. Early Childhoold Research Quarterly 12(3):281-303.

Shamos MH. 1995. The Myth of Scientific Literacy. New Brunswick, NJ: Rutgers University Press.

Shrigley RL. 1990. Attitudes and behavior are correlates. Journal of Research in Science Teaching 27(2):97-113.

Simpson RD, Oliver JS. 1985. Attitude toward science and achievement motivation profiles of male and female students in grades six through ten. Science Education 69(4):511-525.

Simpson RD, Oliver, JS. 1990. A summary of major influences on attitude toward and achievement in science among adolescent students Science Education 74(1):1-18.

Talton EL, Simpson RD. 1985. Relationships between peer and individual attitudes toward science among adolescent students. Science Education 69(1):19-24.

U.S. Department of Health and Social Services. 2002. Good start, grow smart: The Bush administration's early childhood initiative. Washington, DC. 